\title{
Language Rights in Relations with Public Administration: European Perspectives
}

\author{
Iryna Ulasiuk* \\ Robert Schuman Center, European University Institute, San Domenico di Fiesole (FI), Italy
}

\begin{abstract}
The preservation of linguistic diversity has recently become a major concern to many researchers, politicians and leaders of linguistic communities in Europe. The issue of linguistic minorities has taken on a particular urgency because of the increasing recognition of the threat of extinction faced by many minority languages. The need for immediate action has become obvious. Europe has slowly but steadily started to come up with responses to how to keep the most vulnerable languages from extinction and guarantee rights to speakers of such languages at the same time. Today we can talk about the emergence of a European minimum standard of protection of language rights as it has developed since the 1990s in the European conventions and their monitoring activities. There is general understanding that three areas of the use of languages - education, administrative affairs and the media - are determinant for the survival of minority languages. The present article focuses on one of such areas, which has revealed to be particularly contentious and a source of everincreasing concern. It investigates the guarantees provided in the Council of Europe's instruments pertaining to the use of minority languages before public authorities, the practical difficulties and ways of their overcoming in the implementation of the rights enshrined in European treaties.
\end{abstract}

\section{Keywords}

language rights; public administration; Council of Europe; ECHR; FCNM; ECRML

[I] $\mathrm{f}$ a language were to be completely barred from relations with the authorities, it would in fact be negated as such, for language is a means of public communication and cannot be reduced to the sphere of private relations alone. Furthermore, if a language is not given access to the political, legal or administrative sphere, it will gradually lose all its terminological potential in that field and become a 'handicapped' language, incapable of expressing every aspect of community life. ${ }^{1}$

\section{Introduction}

The preservation of linguistic diversity has recently become a major concern to many researchers, politicians and leaders of linguistic communities in Europe.

*) E-mail contact: Iryna.Ulasiuk@eui.eu

1) Explanatory Report to the ECRML, para. 101. 
The issue of linguistic minorities has taken on a particular urgency because of the increasing recognition of the threat of extinction faced by many minority languages.

The need for immediate action has become obvious. Europe has slowly but steadily started to come up with responses to how to keep the most vulnerable languages from extinction and guarantee rights to speakers of such languages at the same time. Today we can talk about the emergence of a European minimum standard of protection of language rights as it has developed since the 1990s in the European conventions and their monitoring activities.

There is general understanding that three areas of the use of languages education, administrative affairs and the media - are determinant for the survival of minority languages.

The present article focuses on one of such areas, which has revealed to be particularly contentious and a source of ever-increasing concern. It investigates the guarantees provided in the Council of Europe's instruments pertaining to the use of minority languages before public authorities.

The argument follows the following structure. The article first exposes the importance of the use of languages in the public domain for minority language speakers. Then the relevance of three European instruments with regard to the discussed right is addressed:

- the language rights potential of the European Convention on Human Rights (ECHR) is assessed;

- the Framework Convention for the Protection of National Minorities' (FCNM) implications as a rights instrument are analysed;

- the European Charter for Regional or Minority Languages (ECRML) is looked upon as an instrument adding additional value to the previous two documents.

Thereafter follows an overview of practical problems encountered by the persons belonging to national minorities in the realisation of the forenamed right and solutions suggested by the monitoring bodies. A short conclusion summarises the basic ideas discussed in the article.

\section{The Importance of the Right to Use a Minority Language before Public Authorities}

As a recent Organization for Security and Co-operation in Europe (OSCE) report says, "the ability of persons belonging to national minorities to communicate with governmental officials and bodies in their own language is an essential linguistic right. It both ensures that they will be able to understand governmental 
policies that affect them and express their views to appropriate governmental instrumentalities."2

The Advisory Committee to the FCNM, hereinafter referred to as "ACFC", has also stressed that "use of minority languages in relations with the administrative authorities is indeed an important means of enhancing the visibility of persons belonging to national minorities and, [...] contributes to the preservation of these languages". ${ }^{3}$

Moreover, Woehrling rightly points out that

bringing out the importance of the regional or minority language by giving it a role in dealings between citizens and the public authorities [...] is the key objective [of the Charter]. In most cases, speakers of the regional or minority language have a command of the official language, as the charter in fact requires. They can therefore resolve any practical communication difficulty by resorting to the official language. The use of the regional or minority language is not, therefore, except in special cases, a practical necessity but a voluntary exercise dictated by the satisfaction felt in speaking the language and the desire to make room for it in dealings with public bodies. A state which accepts this obligation recognises the legitimacy of this wish and undertakes to respect it. It is also a matter of speakers of regional or minority languages being enabled to exercise their citizenship rights and their civic duties in a manner which is consistent with their mode of expression. ${ }^{4}$

What is more, the ability of minorities to use their language in their relations with public authorities allows them, in the opinion of the OSCE experts, "to become actively involved in the civil life of the country in order to create a pluralistic and open society, where members of minority groups feel integrated without having to sacrifice their identity".

The role of a minority language as "a full-fledged vehicle of communication in local political life and in the interface between citizens and public authorities" ${ }^{6}$ becomes even more important, if the number of minority language speakers is significant and they reside compactly within a territory since "it is likely that many have a limited proficiency in the majority or official language because in most contexts of their daily lives these people are in contact with other members of their community and have relatively few occasions or little need to use another language". 7

2) Report on the Linguistic Rights of Persons Belonging to National Minorities in the OSCE Area, p. 12, <www.osce.org/documents/hcnm/1999/03/239_en.pdf >, visited on 25 March 2010.

3) ACFC Second Opinion on Bosnia and Herzegovina, para. 157.

4) J.-M. Woehrling, The European Charter for Regional or Minority Languages: A Critical Commentary (Council of Europe Publishing, 2005) pp. 178-179.

5) Report on the Linguistic Rights ..., supra note 2, p. 12.

6) HCNM, The Oslo Recommendations Regarding the Linguistic Rights of National Minorities, Explanatory Report, principles 13-15.

7) F. De Varennes, Language, Minorities and Human Rights (Kluwer Law International, The Hague, 1996) p. 176. 
In point of fact, however, the right of persons belonging to minorities to use their language in relations with public authorities is a rather contradictory right which, as De Varennes argues, "directly confronts the issue of whether an official language must necessarily be exclusively favoured and used by the state's apparatus and officials". ${ }^{8}$

Moreover, it is also a right that is not widely enshrined in international legal instruments, and thus not generally the subject of international decisions to delimit its boundaries and content.

In addition to Article 10 of the Framework Convention, only Article 10 of the European Charter for Regional or Minority Languages sets forth a legal obligation to have minority languages used in dealings with public authorities.

Notwithstanding this, in a number of cases, the public authorities have been obligated to use a minority language in dealings with minorities under traditional human rights in circumstances where the exclusive use of the state language has been deemed unreasonable or unjustified, and thus discriminatory towards minority language speakers. In Diergaardt v. Namibia ${ }^{9}$ the UN Human Rights Committee has confirmed that states cannot reject a request for the provision of services and information in a minority language if it is not well justified. The European Court of Justice has also acknowledged language as a "service" or "benefit" for citizens of the EU which cannot be denied in a discriminatory manner. ${ }^{10}$

What the above suggests is that the right of minority speakers to have their language used in the public domain is far from being a well-established legal guarantee in international law. As a result, the exact content which gives rise to such a right is rather uncertain due its limited presence ${ }^{11}$ in treaties.

8) F. De Varennes, 'Article 10', in M. Weller (ed.), The Rights of Minorities in Europe: A Commentary on the European Framework Convention for the Protection of National Minorities (Oxford University Press, 2005) p. 309.

9) Diergaardt v. Namibia (No.760/1997), UN Doc. CCPR/C/69/D/760/1997 (2000). Under the Constitution, English was the only official language in Namibia. Staff members in local public offices were instructed by the government not to communicate with the public in any language other than English, although public servants could speak the minority language in question (form of Afrikaans) and at least some of the members of the community allegedly could not speak English. The UN Human Rights Committee found this to be a violation of Article 26 of the International Covenant on Civil and Political Rights. Whereas the grounds for this conclusion were not spelled out, a strong but plausible reading of this case, from my point of view, would be that the denial of minority language public services to minority language speakers who cannot speak the state language constitutes a violation of the right to equal protection under the law.

For a detailed analysis of the case, see A. H. E. Morawa, 'Minority Languages and Public Administration A Comment on Issues Raised in Diergaardt et al. v. Namibia', ECMI Working Paper No. 16 (2002), pp. 1-9.

10) Case 137/84 Ministère public v. Mutsch [1985] ECR 2681, and Case C-275/96 Bickel and Franz v. Italy [1998] ECR I-7637.

11) De Varennes, supra note 8, p. 310. 


\section{European Convention on Human Rights}

The European Convention does not include any provisions expressly relating to the use of languages before administrative authorities. However, if language is to be considered as an integral part of the freedom of expression, ${ }^{12}$ one might logically suppose that Article 10 of the ECHR guaranteeing this freedom can be invoked when claiming the right to use minority language in relations with public authorities. However, the analysis of the case law shows that the situation is not as clear as it might seem at the beginning.

In the case of Inhabitants of Leeuw - St. Pierre v. Belgium, ${ }^{13}$ Belgian citizens living in a Flemish municipality requested their municipality to provide them with documentation in French. Their request was refused, which, as the applicants claimed, violated their right to freedom of expression guaranteed by Article 10. However, the European Commission of Human Rights found that the claim was inadmissible as the ECHR does not explicitly guarantee "linguistic freedom" when attempting to employ the right to use a minority language before municipal authorities.

In $X$ v. Ireland, ${ }^{14}$ the language choice and freedom of expression was again an issue under consideration; however, the Commission found that there was no violation in the requirement to fill in a form in Irish, the first official language of Ireland, even though the applicant was English-speaking.

Finally, in Fryske Nasjonale Partij v. Netherlands ${ }^{15}$ the applicants claimed that their right to freedom of expression had been violated because they were unable to stand as candidates in an election because their registration for the election was not in Dutch but in Frisian. Here the Commission decided that freedom of expression does not guarantee the right to use the language of one's choice in administrative issues.

As we can see from this case law, the Commission has not expressly considered the issue of choice of language as part of freedom of expression.

When the issue was discussed in the Ballantyne, Davidson and McIntyre case, ${ }^{16}$ the United Nations (UN) Human Rights Committee made a very important distinction which directly affects the right to use a language of one's choice, also before public authorities. Namely, the United Nations Human Rights Committee distinguished between public and private affairs. It stated: "A State

\footnotetext{
12) At a national level it is often the case, while in international law the situation is not that straightforward. See F. de Varennes, 'Language and Freedom of Expression in International Law', 16:1 Human Rights Quarterly (1994) pp. 166-167.

13) 8 Yearbook of the European Convention on Human Rights (1965) p. 338.

14) 13 Yearbook of the European Convention on Human Rights (1970) p. 792.

15) 45 Decisions and Reports (E. Commission of HR) (1986) p. 240.

16) The case dealt with the use of languages in commercial signs in Canada. See the detailed analysis of the case in De Varennes, supra note 12, pp. 176-177.
} 
may choose one or more official languages, but it may not exclude, outside the spheres of public life, the freedom to express oneself in a language of one's choice." ${ }^{17}$

As Higgins put it, "this case could be seen as a success for those campaigning for language rights, with the Committee finally recognising a link between language choice and freedom of expression". ${ }^{18}$ The analysis of the case law of the European Commission and the European Court of Human Rights shows that they have come to the same conclusion: anyone has the right to give and receive information in the language of their choice to anyone, including the public authorities, but the public authorities are not obliged to receive or to respond to such information in the applicant's language. The state can function in the official language exclusively, and it can require its citizens to use this language when dealing with public authorities. However, outside the ambit of public affairs, anyone may express him or herself in the language of his or her choice. While this may place minority language speakers at a disadvantage in relations with public authorities, this is justified in most cases in the "public interest". In case this disadvantage is unreasonable or unjustified, it can give rise to a case of discrimination on the grounds of language. ${ }^{19}$

However, as de Varennes points out,

\begin{abstract}
[u]nfortunately, neither the European Commission nor the Human Rights Committee clearly stated that this [distinction between private and public affairs] was the reason for which they chose to treat the freedom of expression arguments as inadmissible in almost every case. Although one sometimes gets the impression from the European Commission that language is implicitly a part of freedom of expression when dealing with private matters, the Commission never actually spelled the principle out properly, and until recently an uncomfortable degree of uncertainty remained. ${ }^{20}$
\end{abstract}

Some authors refer to this state of affairs as "a coming problem" to resolve, ${ }^{21}$ and due to the increasing attention paid to minority issues by the Council of Europe (as exemplified by the FCNM and ECRML discussed below) do not exclude that the existing practice might be reconsidered:

If the question were raised again before the [European] Commission or the Court, those institutions might well find that freedom of expression includes the freedom of linguistic

17) Ballantyne, Davidson, McIntyre v. Canada, Communications Nos. 359/1989 and 385/1989, 1993, Point 11.4.

18) N. Higgins, 'The Right to Equality and Non-Discrimination With Regard to Language', 10:3 Murdoch University Electronic Journal of Law (2003).

19) As in the case of Diergaardt v. Namibia mentioned above.

20) De Varennes, supra note 12, p. 179.

${ }^{21)}$ D. J. Harris, M. O'Boyle and C. Warbrick, Law of the European Convention of Human Rights (Butterworths, 1995) p. 379. 
expression. Freedom of expression would not only protect the message or content (opinions, information, thoughts, emotions), but also the indispensable form or medium of a given language. ${ }^{22}$

In the meantime, what has been left out by the ECHR has been addressed in two more minority-specific documents - the FCNM and ECRML. How they deal with the issue under discussion is analysed below.

\title{
4. Framework Convention for the Protection of National Minorities
}

The Framework Convention provides the following in Article 10(2):

In areas inhabited by persons belonging to national minorities traditionally or in substantial numbers, if those persons so request and where such a request corresponds to a real need, the Parties shall endeavour to ensure, as far as possible, the conditions which would make it possible to use the minority language in relations between those persons and the administrative authorities.

How shall this provision be interpreted in practical terms? It would seem that where national minorities need to communicate with governmental institutions in their own language, typically, though not exclusively, in those regions where they are concentrated or have lived traditionally, the government should make every effort to make this possible. It does not necessarily mean, however, that the government is obligated to accommodate every such person in every situation. Financial constraints may well come into play: ${ }^{23}$

\begin{abstract}
This right in relation to the use of a minority language by public officials is quite variable. It is not a right to a language, it is not a right which appears every time there is a minority language or a demand to use a minority language, it is only a right which arises, essentially, when there are substantial speakers or sufficient speakers of a language demand a certain type of public service in their language. It actually means that where the numbers of speakers of a minority language are too low, or it is too onerous to use a minority language in a certain type of public service, it is not a violation of a language or minority right for public officials not to use this language. ${ }^{24}$
\end{abstract}

22) B. de Witte, 'Surviving in Babel? Language Rights and European Integration', in Y. Dinstein, and M. Tabory (eds.), The Protection of Minorities and Human Rights (Martinus Nijhoff, Dordrecht, 1992) p. 281.

23) Explanatory Report on the Framework Convention for the Protection of National Minorities, paras. 64-66; OSCE, Oslo Recommendations Regarding the Linguistic Rights of National Minorities, Explanatory Note, para. 29.

24) F. De Varennes, 'Language Rights as an Integral Part of Human Rights', 3:1 International Journal on Multicultural Societies (2001) p. 20. 
The compromise formulation of Article 10(2) point to several qualifications, which due to their ambiguity and "flexibility" have been extensively interpreted by the drafters of the Framework Convention themselves in the Explanatory Report and by the Advisory Committee in its monitoring practice.

A few points are worthy of particular attention.

First, the Explanatory Report makes it clear that Article 10(2) refers to administrative authorities only, though the latter must be broadly interpreted. ${ }^{25}$

Second, the drafters stress that parties are left with a wide measure of discretion. However, this discretion is not unlimited. Once the conditions stipulated in Article 10(2) are met, the "[p]arties shall endeavour to ensure the use of a minority language in relations with the administrative authorities as far as possible".

Third, an inevitable question on the balance between the state and minority languages arises. And here several points need to be singled out.

While there seems to be no need for the minority languages to be raised to the status of state languages for minorities to be able to use them in their relations with authorities, caution should be taken not to downgrade the minority language status to that of a foreign language and in this way limit the opportunities which the European documents open before the minority representatives. This was the case in the Polish context, where the Advisory Committee has expressed their concern in the following terms:

The Advisory Committee is concerned that this Decree, which treats minority languages as foreign languages and applies the same restrictive rules to both categories, risks sending the public an unfortunate signal as to the place of minority languages and cultures in Polish society. The Advisory Committee therefore expresses the hope that the term "foreign languages" will no longer be referred to in legislation in relation to the use of minority languages. The legitimate needs of minority languages and cultures are very different from those of foreign languages, and it is important to treat them separately instead of reducing their level of protection to the lowest common denominator. ${ }^{26}$

The Explanatory Report deals with the impact of the discussed language rights on the status of a state's official language as follows:

The Parties' obligations regarding the use of minority languages do not in any way affect the status of the official language or languages of the country concerned. ${ }^{27}$

25) Explanatory Report on the Framework Convention for the Protection of National Minorities (1995), Article 10(2), (64).

26) ACFC Opinion on Poland, para. 69. A similar situation is Germany where the existing provisions allowing for the submission of documents in a "foreign language" also apply to the traditional regional and minority languages and reflect a view prevailing among the authorities that these languages are just foreign languages as opposed to German. See Report of the Committee of Experts on Germany, Initial monitoring cycle, para. 148.

27) Explanatory Report on the Framework Convention for the Protection of National Minorities, para. 66. 
Thus, Article 10(2) must not be interpreted as undermining or downgrading the status of the state language; it just suggests that there exist circumstances where the state language cannot be the exclusive language of dealings with public authorities but minority languages may well be used alongside the state language.

On the other hand, "while recognising the legitimacy of the aim to protect and promote the state language", "it [is] instrumental that such protection and promotion is carried out in a manner that fully protects the rights contained in the Framework Convention", as such is not detrimental to the use of minority languages but is carried out in parallel with the "increased support for minority languages" ${ }^{28}$ Moreover, even in cases where persons belonging to minorities also speak the state language, authorities are encouraged to "look into how and under what circumstances a minority language can be used with the authorities": ${ }^{29}$

[A] good command of the State language is not a reason to refrain from encouraging the use of minority languages in the public sphere and from introducing positive measures in accordance with Article 10 of the Framework Convention. Supporting the use of minority languages in relations with the administrative authorities, when the conditions of Article 10 (2) are met, substantially contributes to the preservation of these languages. Furthermore, it is also a way to ease access of persons belonging to national minorities to a number of public services and therefore, to promote their equal opportunities. ${ }^{30}$

In such cases the Advisory Committee suggests a number of measures that could be easily undertaken to give recognition of the bilingual heritage of the region:

These measures could be quite simple, such as staff of the administration indicating that they are bilingual (notices indicating languages spoken on their desks, badges on their lapels, etc.), prominence being given to translations of texts where available, etc. Such simple steps could also provide an important form of public recognition to the presence of the German minority in the region. ${ }^{31}$

Fourth, as mentioned above, the exercise of the right to use a minority language in public domain stipulated by Article 10(2) is subject to various restriction clauses which makes the enjoyment of the right dependent on such preconditions as numerical minima or geographical area and the "possibility" and "necessity" criteria.

Let us briefly address these limitations.

28) ACFC Opinion on Azerbaijan, para. 53; on Estonia, para. 39; on Russia, paras. 80-81; on Sweden, para. 46; ACFC Second Opinion on Sweden, para. 98.

29) ACFC Second Opinion on Denmark, para. 130; ACFC Opinion on Germany, para. 49.

30) ACFC Second Opinion on Azerbaijan, para. 117.

31) ACFC Second Opinion on Denmark, para. 133. 
The first of the three restrictions, namely "significant number/proportion", does not contain a specific percentage or number at which public authorities shall be obligated to use a minority language in their relations with minority speakers. In this way the drafters tried to enable state parties to take into consideration their particular circumstances.

In its opinions on Austria, Romania and the Slovak Republic, the Advisory Committee found a 10 per cent threshold (in Austria), and a 20 per cent threshold (in Romania and Slovak Republic) to be "an important step in the implementation of the Framework Convention". At the same time, the majority criterion adopted in Bosnia and Herzegovina, Croatia and Moldova was found to be so "high that it might constitute an obstacle with respect to certain minority languages in areas inhabited by persons belonging to national minorities either traditionally or in substantial numbers, particularly at the level of local communities". 32

Moreover, as the Explanatory Report indicates, the Framework Convention also deliberately refrains from defining "areas inhabited by persons belonging to national minorities traditionally." In De Varennes's words, the term refers to areas "where one usually finds minorities geographically concentrated, but this concentration does not necessarily need to be a historical one". ${ }^{33}$ De Varennes further suggests the application of the so-called "sliding-scale model": authorities provide an increasing level of services in minority languages as the number of their speakers increases. The authorities will start with bilingual or minority language forms and documents, then their duty will be to accept petitions and respond to them in a minority language, and ultimately a "bilingual administration" will be exercised. ${ }^{34}$

The second restriction, namely "as far as possible" 35 or "reasonably possible", ${ }^{36}$ is probably the most far-reaching limitation used in both Council of Europe documents under investigation: the FCNM and ECRML. This would seem to mean that state parties "must act to the maximum of their abilities and resources in using a minority language, consistent with the overall object and intent to protect national minorities". ${ }^{37}$ Not surprisingly, as Morawa remarks, these limitation clauses "enable states to advance a range of arguments preventing them from giving full effect to 'administrative language rights"' and thus underscore the fact

32) See ACFC Opinion on Austria, para. 45; on Romania, para. 49; on Croatia, para. 43; on Moldova, paras. 61-62; ACFC Second Opinion on Slovak Republic, paras. 86-87; ACFC Second Opinion on Bosnia and Herzegovina, paras. 159-160.

33) De Varennes, supra note 8, p. 313.

34) De Varennes, supra note 24, p. 21.

35) Introduced by the Venice Commission in Article 8 of its Proposal and incorporated into Article 10(2) of the Framework Convention.

36) ECRML, Article 10(1).

37) De Varennes, supra note 8, p. 311. 
that the provisions concerned are worded "very flexibly, leaving Parties a wide measure of discretion". 38

The third restriction, namely the "necessity requirement", comprises the socalled "desire" or "request" on the part of minority groups to use their languages in their dealings with the public authorities, on the one hand, and the so-called "real need", on the other hand. The "desire" ideally must "correspond" to the "need". The two concepts, however, Morawa argues, are not as distinct as they may look on the surface:

\begin{abstract}
While the term "desire" sounds as if it meant (a) an expression of a wish made by the relevant minority without state interference and (b) an essentially subjective decision, the drafting history suggests that that is not necessarily so. The Portuguese delegation to CAHMIN, for instance, emphasized that states "shall in particular endeavour to ensure that such requests are assessed on the basis of objective and non discriminatory criteria [...]" Thus, states seem to retain the competence to 'assess' desires but, in doing so, must not act arbitrarily. As a consequence, the 'desire' and 'real need' elements are not as different as the terms would suggest. ${ }^{39}$
\end{abstract}

On the basis of this, the meaning of the desire/real need clause can be summed up as follows: in an area inhabited traditionally by minorities from which there is a request which corresponds to a real need, a state party is entitled to ensure the use of minority languages by administrative authorities as far as it is possible due to the state's concrete (including financial) circumstances. Meeting one of the criteria, either "substantial numbers" or an area traditionally inhabited by a national minority, is sufficient for the right under discussion to become effective.

Another important point is to be mentioned in the context of the limitation under consideration. As previously articulated, the linguistic rights guaranteed under Article 10 are not dependent on minority speakers' ability to communicate in the state's official language. Even if members of a minority are able to use and understand the official language perfectly, they can still have administrative authorities use their own language, "as far as possible".

Finally, it is not enough to have legislation that conforms to Article 10(2) in place; its effective implementation is a true key to the enjoyment and exercise of the right to have authorities use a minority language.

\title{
5. European Charter for Regional and Minority Languages
}

The Language Charter sees the use of minority languages by administrative authorities as an important pre-condition for the survival of regional or minority

\footnotetext{
38) Morawa, supra note 9, p. 18.

39) Ibid., p. 19.
} 
languages. ${ }^{40}$ It deals with the question of how linguistic diversity can be managed in the public sphere in Article 10. The Article is shaped by two principle ideas.

First and foremost, the particular situation of each regional or minority language should be taken into consideration. In Morawa’s words:

The Language Charter's 'according to the situation of each language'-qualification in Article 10 may in fact serve as a purposeful guiding light for states if and as far as it is understood as requiring an objective assessment of the "situation" and as demanding that states pay due attention to the (objective and - thereby having regard to the minority group's point of view - subjective) vulnerability of the language in question and the corresponding need for protection. ${ }^{41}$

Second, as Woehrling puts it, "any theoretical or principle-based approach should be avoided in the interest of practical, reasonable solutions". ${ }^{42}$ He explains that the pragmatic and practical approach the Charter adopts is conditioned by a number of difficulties associated with the realisation of the right to have public authorities use a minority language. He points to the symbolism attached to the right to use a minority language by both public authorities and its speakers; misunderstandings in the implementation of the right (for example, the "all or nothing" criterion this right is often mistakenly labelled with); and finally practical constraints of the right (financial difficulties, specific adjustments needed in the staff recruitment and training procedures, translation/interpretation difficulties, etc.). ${ }^{43}$

In principle, the Charter only identifies measures to be used by administrative bodies:

- in areas where these measures may be justified by the number of minority language speakers; ${ }^{44}$

- according to the situation of the language concerned; ${ }^{45}$

- and should only be applied as far as it is reasonably possible to do so. ${ }^{46}$

40) Explanatory Report, para. 10.

41) Morawa, supra note 9, p. 20.

42) J.-M. Woehrling, 'Problems Raised by the Use of Regional or Minority Languages before Public and Judicial Authorities', in International Conference on the European Charter for Regional or Minority Languages, Regional or Minority Languages No. 1 (Council of Europe Publishing, 1998) p. 28.

43) Woehrling, supra note 42, pp. 25-28.

44) Article 10(1), (2) and (3). Unlike the Advisory Committee, the Committee of Experts made very few references to the numerical thresholds giving rise to the right to use a regional or minority languages before public authorities. However, when the Committee of Experts analysed the 20 per cent requirement set by the Slovakian law, it came to the conclusion that it was excessive for the proper implementation of the Language Charter. Report of the Committee of Experts on Slovakia, initial monitoring cycle, para. 131.

45) Article $10(1),(2)$ and (3). In its evaluation reports, the Committee of Experts remarked repeatedly that the situation varies greatly between the languages. See, as an illustration, Report of the Committee of Experts on Armenia, initial monitoring cycle, para. 105.

46) Article 10 (1), (2) and (3). The drafters stressed that the inclusion of this qualification was made in order to recognize that "there may be some circumstances in which total and unqualified 
Thus, similar to the Framework Convention, the Language Charter includes several "escape clauses". But, unlike the former, the latter prescribes the obligations of the state parties more precisely. It offers a number of measures with varying levels of difficulty and requires authorities to recognise regional or minority languages to varying degrees: it sets forth the requirement that minority language speakers may submit oral or written applications or documents and receive a reply in these languages; ${ }^{47}$ to make available widely used administrative texts and forms for the population in the regional or minority languages or in bilingual versions; ${ }^{48}$ to allow the administrative authorities to draft documents in a regional or minority language ${ }^{49}$ the publication by local authorities of their official documents also in the relevant regional or minority languages $;{ }^{50}$ and the use by regional authorities of regional or minority languages in debates in their assemblies. ${ }^{51}$

These undertakings are fulfilled through: translation or interpretation; ${ }^{52}$ recruitment and training of the officials and public service employees; and compliance as far as possible with requests from public service employees having knowledge of a regional or minority language to be appointed into the area in which that language is used. ${ }^{53}$

In an attempt to identify sensible solutions to the problems of the use of regional or minority languages in the public domain, the Charter differentiates between:

(1) state authorities and local authorities: in areas where regional or minority languages are used, the presence of a local minority self-government could become the basis for the concrete implementation of the obligations under Article 10. Thus, the Committee of Experts strongly urged the Hungarian authorities:

without minimizing the existing linguistic rights applying to the whole territory of Hungary, to designate those local and regional authorities, on whose territory local and county minority self-governments representing Part III languages are active, as the authorities that will be obligated to take organisational measures to implement the obligations under Article $10 .^{54}$

application of the provision in question is not, or not yet, realistic. The phrase 'as far as this is reasonably possible' allows the parties, in the implementation of the relevant provisions, to determine in individual cases whether such circumstances obtain." Explanatory Report, para. 104.

47) Article 10(1)(a).

48) Article 10(1)(b).

49) Article 10(1)(c).

50) Article 10(2)(c).

51) Article 10(2)(f).

52) However, as Woehrling stresses, "documents needing translation can be dealt with selectively: it is possible to translate only local texts and documents intended for the local population, rather than systematically translating every document". See Woehrling, supra note 42, p. 30. See also Report of the Committee of Experts on Switzerland, initial monitoring cycle, para. 107.

53) Report of the Committee of Experts on Germany, second monitoring cycle, para. 578; on Serbia, initial monitoring cycle, para. 206.

54) Report of the Committee of Experts on Hungary, third monitoring cycle, para. 133; on Norway, second monitoring cycle, para. 120. 
(2) executive bodies and assemblies within local authorities themselves. The Charter seems to imply that, at least in the case of assemblies, elected representatives shall perform their duties using their native language. As Woehrling remarks: "It therefore seems difficult to deny speakers in assembly debates the right to use the regional language in the area where it is spoken." 55

However, practice shows that the use of minority languages in the debates in assemblies is not so obvious after all. In the evaluation report on the application of the Charter in Finland, the Committee of Experts drew attention to the rare use of Sami in debates in local assemblies. It specified that the reason is that interpretation is not always available and the speakers would allegedly be stigmatised. The Committee of Experts called on the authorities to introduce measures of encouragement in this respect. ${ }^{56}$ In Hungary, in most municipalities with a significant number of minority language speakers, the use of minority languages seems limited to symbolical introductory remarks while the main oral contributions are made in the state language and decisions and minutes are drawn up in the state language. The Committee of Experts encouraged the authorities to promote the oral and written use of minority languages by local authorities in debates in their assemblies. ${ }^{57}$

Provision of simultaneous interpretation could be one suitable way to encourage the use of minority languages in debates in assemblies and promote effective participation in their work. ${ }^{58}$

(3) regulatory administrative bodies and service-providers: it is easier to use a local language in providing services than in drawing up regulations. Here the Committee of Experts indicated that to facilitate the process and to make it clear to the speakers of minority languages that they may submit requests in their language and to ensure that public services concerned are aware of this, it would be advisable that corresponding instructions (or where necessary, formal legal rules) are issued to the authorities and made public..$^{59}$

\section{external and internal use of languages}

(a) External relations of state agencies, local governments with the general public are accompanied by requests submitted to the authorities and the responses given

\footnotetext{
55) Woehrling, supra note 42, p. 29.

56) See Report of the Committee of Experts on Finland, initial monitoring cycle, para. 164 and second monitoring cycle, para. 129.

57) Report of the Committee of Experts on Hungary, third monitoring cycle, paras. 150-151.

58) See Report of the Committee of Experts on Switzerland, third monitoring cycle, para. 97; on the UK, initial monitoring cycle, para. 251.

59) Report of the Committee of Experts on Germany, initial monitoring cycle, paras. 92, 223, 263, $266,300,303,332,362,364$.
} 
by the latter. The monitoring practice of the Committee of Experts seems to indicate that while admittance of requests in a minority language poses no particular difficulties, problems arise with regard to replies. These ideally may be drawn up in the same language as requests received ${ }^{60}$ or may automatically be dispatched in the state language (unless the person or institution concerned has expressly requested that a minority language be used ${ }^{61}$ or may be given in a minority language only orally ${ }^{62}$ due to the lack of competence on the part of the authority concerned in producing written documents in a minority language, ${ }^{63}$ etc. The following solution has been identified by the Committee of Experts in the case of Sweden to address the above-mentioned problems, which are quite common in other countries as well:

A structured human resources policy, taking account of civil servants' oral and written proficiency in Sami, for recruitment as well as for in-house further training, would be the most appropriate solution to these shortcomings. ${ }^{64}$

(b) Internal relations presuppose relations between public service employees and therefore the working language of the authorities themselves. The working language can be decided upon by the employees themselves or regulated by the administrative authorities to the extent it does not hamper administration:

The undertaking [...] does not call for any systematic use of the language, and indeed its use may be combined with use of the official language or languages. The undertaking must be understood as requiring the regional or minority language to have a significant place in the work of the authorities, but it is up to them to decide how it will be used. ${ }^{65}$

Finally, Article 10(5) introduces another aspect, which has received separate treatment in minority rights instruments: the parties undertake "to allow the use or adoption of family names in [...] regional or minority languages, at the request of those concerned". Article 10(5) should be construed as an additional encouragement to states to adopt a names regime - the right to a name in the minority

60) See Report of the Committee of Experts on Switzerland, initial monitoring cycle, para. 128.

61) See Report of the Committee of Experts on the Application of the Charter in the Switzerland, initial monitoring cycle, para. 223.

62) See Report of the Committee of Experts on the Application of the Charter in Sweden, initial monitoring cycle, paras. 221 and 337 and third monitoring cycle, para. 245.

63) Report of the Committee of Experts on Sweden, second monitoring cycle, para.122. See also RecChL(2006) 4 Recommendation 5 where the Committee of Ministers encouraged the oral and written use of minority languages by the Swedish authorities.

64) Report of the Committee of Experts on Sweden, second monitoring cycle, paras. 124 and 269.

65) Woehrling, supra note 4, p. 183. See also Report of the Committee of Experts on the Application of the Charter in Croatia, third monitoring cycle, paras. 144-147, where the Committee of Experts concluded that regional or minority languages are not often used internally, only in those cases, for example, where the speakers constitute a large majority of the staff. 
language and the official recognition of the name inscribed in the Framework Convention. ${ }^{66}$ All ratifying states have exceeded their minima in relation to Article 10 and agreed to a relatively large number of undertakings. The names provision is one of the least controversial provisions and has been accepted by most ratifying states concerned for minority languages.

\section{Common Practical Problems and Solutions in the Realisation of the Right to Use a Minority Language before Public Authorities}

In practice, the realisation of the right to use a minority language before public authorities is hindered by a number of recurring difficulties. Both the Advisory Committee under the FCNM and the Committee of Experts under the ECRML, focusing in their monitoring activities on actual practice, precise statistics and concrete national situations, have devoted substantial attention to such difficulties. By assessing whether the states have complied with their obligations, the expert bodies have formulated opinions on how to improve the situation in the countries concerned.

What becomes obvious from the monitoring reports is that it is the lack of clarity in the existing legislative framework, ${ }^{67}$ exacerbated by the absence of a structured policy with regard to the use of minority languages ${ }^{68}$ (minority languages are used on an ad-hoc basis at the local level ${ }^{69}$ and economic constraints, including costs of translation of documents, ${ }^{70}$ that make the use of minority languages before the authorities in a number of countries particularly difficult.

What is more, it is not infrequent that while the general legislative framework for the discussed right is in place, it is not operational either because of the lack of implementation or encouraging measures, ${ }^{71}$ or because its implementation is dependent far too strongly on the willingness of the local authorities. ${ }^{72}$ As the Committee of Experts concluded in its report on Croatia, "the combined effect of the existence of a [numerical] threshold and the arbitrary power [to decide on the application of the Article 10 of the Charter] left to the local authorities leads

\footnotetext{
66) Article 11(1).

67) ACFC Second Opinion on Estonia, para. 40; ACFC Opinion on Armenia, para. 101; on Albania, para. 99; on the Czech Republic, para. 55. See more on the point De Varennes, supra note 8, pp. 314-315.

68) See the Report of the Committee of Experts on Austria, para. 247; on Croatia, para. 177; on Germany, Finding E. All the reports are from second monitoring cycle.

69) Report of the Committee of Experts on Croatia, third monitoring cycle, para. 226.

70) ACFC Second Opinion on Armenia, para. 80; on Finland, para. 111.

71) Report of the Committee of Experts on Austria, second monitoring cycle, Finding D; on Germany, initial monitoring cycle, para. 494; on Sweden, initial monitoring cycle, para. 112; on Finland, initial monitoring cycle, para. 167; on Hungary, initial monitoring cycle, para. 55.

72) ACFC Second Opinion on Austria, para. 120; ACFC Second Opinion on Romania, para. 127.
} 
to poor or non-existent use of minority languages before public authorities" ${ }^{73} \mathrm{As}$ a consequence, although local authorities undoubtedly have an important role to play in relation to the use of minority languages in specific circumstances, there seems to be a need for them to comply with central government legislation laying down general rules on the use of minority languages and giving local authorities scope to adapt the latter to local circumstances as necessary in order to respond more effectively to the demands voiced. ${ }^{74}$

In many situations the use of a minority language in the public domain is difficult or impracticable because of the lack of linguistic skills among civil servants, which is not surprising due to the very limited incentives for them to learn minority languages. ${ }^{75}$ As the Committee of Experts remarked in their report on Sweden "language competence is very rarely seen as a merit or a special qualification in job announcements" ${ }^{76}$ It would, thus, seem logical when recruiting civil servants to focus on those who are proficient in minority languages when this is deemed necessary for the performance of their concrete duties. ${ }^{77}$

A positive example of the incentives to be used is found in Slovenia, for instance, where the knowledge of a minority language is rewarded financially ( 6 per cent salary increase for active use and 3 per cent salary increase for passive knowledge). ${ }^{78}$

At the same time, there are cases, as in Denmark, for example, where an important number of public service employees do have a good command of a minority language (German), but still minority language speakers never address the administration in their language. ${ }^{79}$

Why? The reasons vary. The lack of demand for the use of minority languages in relations with administrative authorities and public services may be conditioned by the absence of supply and tradition. ${ }^{80}$

\footnotetext{
73) Report of the Committee of Experts on Croatia, second monitoring cycle, para. 198. See also Report of the Committee of Experts on Hungary, second monitoring cycle, para. 101.

74) ACFC Second Opinion on Albania, para. 145; ACFC Second Opinion on Austria, para. 120.

75) ACFC Second Opinion on Austria, paras. 119 and 121; ACFC Second Opinion on Slovak Republic, para. 88; ACFC Opinion on Slovenia, para. 52. See also Reports of the Committee of Experts on Austria, initial monitoring cycle, para. 251; on Hungary, second monitoring cycle, para. 114 and Finding E; on Finland, initial monitoring cycle, para. 106 and third monitoring cycle, para. 230, (here a lack of interpreters/translators has come to the fore); on Germany, initial monitoring cycle, para. 494.

76) Report of the Committee of Experts on Sweden, initial monitoring cycle, para.112.

77) ACFC Opinion on Hungary, para. 35; ACFC Second Opinion on Hungary, para. 83; Report of the Committee of Experts on Hungary, second monitoring cycle, para. 100. See also Principle 14 of the Oslo Recommendations, which calls on authorities to "adopt appropriate recruitment and/ or training policies and programmes".

78) Report of the Committee of Experts on Slovenia, initial monitoring cycle, para. 124.

79) Report of the Committee of Experts on Denmark, initial monitoring cycle, para. 85.

${ }^{80)}$ Report of the Committee of Experts on Hungary, third monitoring cycle, para. 134. See also ACFC Opinion on Serbia, para. 79; ACFC Opinion on Hungary, para. 35; ACFC Opinion on
} 
It may be because of significant delays and other inconveniences for the minority speakers in their dealings with administrative authorities in minority languages. ${ }^{81}$ For example, the Committee of Experts has drawn attention to this type of situation in Hungary: there is a strong reservation on the part of state authorities towards documents drawn up in minority languages, since the public authorities (beyond the level of local communities) are not organisationally equipped, in particular not staffed with adequate personnel, to process such documents. Because the users of minority languages know that their counterparts in administration are not prepared to deal with documents in minority languages, they understandably hesitate to make use of the right. ${ }^{82}$

And in Slovenia where "Hungarian speakers are in general reluctant to use Hungarian, for fear of being seen as 'trouble-makers"' ${ }^{83}$ It may also be because minority representatives lack information on the existence of the right under discussion and corresponding national legislation. ${ }^{84}$ Simple measures can often be quite efficient to remedy the described situation, namely making administrative forms in minority languages more automatically available, ensuring that plates and door plates used in administration offices are, in practice, bilingual, employees putting signs on their doors announcing their command of minority languages, etc. ${ }^{85}$

On a more general scale different steps should be taken to improve the existing situation and promote the use of minority languages before the public administration.

First and foremost, there must be adopted a legal framework on the basis of clearly defined criteria on which national minorities must first be consulted, and which should take due account of the demands voiced by persons belonging to minorities and allow the local authorities to decide on a facilitated use of minority languages, taking into consideration the local circumstances. ${ }^{86}$

Kosovo, para. 77; ACFC Opinion on Montenegro, para. 73. See also Recommendation $\operatorname{Rec} \operatorname{ChL}(2007) 6$ of the Committee of Ministers on the Application of the Charter in Denmark, Recommendation 2.

81) ACFC Opinion on Sweden, para. 49.

82) Report of the Committee of Experts on Hungary, initial monitoring cycle, para. 54.

83) Report of the Committee of Experts on Slovenia, second monitoring cycle, para. 94. See also Report of the Committee of Experts on Sweden, initial monitoring cycle, paras. 112 and 120; on Germany, initial monitoring cycle, para. 447; on Switzerland, initial monitoring cycle, para. 106.

84) ACFC Opinion on Sweden, para. 49; Report of the Committee of Experts on Croatia, third monitoring cycle, para. 140; on the UK, second monitoring cycle, para. 355; on Sweden, initial monitoring cycle, paras. 117 and 227; on Slovakia, initial monitoring cycle, paras. 226, 327 and 409; on Serbia, initial monitoring cycle, para. 178.

85) Report of the Committee of Experts on Hungary, second monitoring cycle, para. 101, and Report of the Committee of Experts on Germany, initial monitoring cycle, para. 147.

86) ACFC Second Opinion on Albania, para. 146, ACFC Second Opinion on Austria, para. 122; ACFC Opinion on Kosovo, para. 77; ACFC Opinion on Bulgaria, paras. 78-79; ACFC Opinion 
Providing clarity on the obligations of local authorities would also substantially contribute to decreasing tensions around the issue of language use. ${ }^{87}$

Second, the lack of comprehensive statistical information on the use of minority languages in contacts with the administration have proved to have a negative impact on the elaboration of targeted policies aimed at improving the use of minority languages in the public sector. ${ }^{88}$ The situation in the UK with regard to the Welsh language can serve as a good practice example: those bodies that have adopted a Welsh language scheme are required to make an annual report on its implementation to the Welsh language board, which in return makes an evaluation and if necessary provides recommendations. ${ }^{89}$

Thus, examining the minorities' needs as regards the public use of their languages and, in co-operation with them, taking the necessary legislative and practical steps to meet those needs, in accordance with the standards set by the FCNM and the ECRML, would be the appropriate behaviour under these documents. ${ }^{90}$

Third, an important pre-requisite for the successful implementation of the right under discussion is without doubt the allocation of adequate means, including support for in-service and other language training and education aimed at ensuring the availability of personnel with adequate minority language skills ${ }^{11}$ as well as support for awareness raising, which are the necessary measures to satisfy the demands of the linguistic communities in their relations with public authorities. $^{92}$

Finally, more generally, the public authorities should pursue a pro-active, open and pragmatic approach with regard to the use of minority languages in dealings with administration. ${ }^{93}$ As the Committee of Experts noted with regard to practices in Croatia:

In general the Croatian authorities seem to be receptive to the needs and wishes of the regional or minority language speakers [...] However, the Charter implementation demands from the state parties a pro-active approach to each undertaking they entered into, whereas the Croatian authorities often content themselves with the fact that there have neither been requests nor complaints on behalf of the regional or minority language speakers. Although many regional

on Armenia, para. 59, ACFC Opinion on Azerbaijan, para. 57; Report of the Committee of Experts on Croatia, initial monitoring cycle, para. 62 and Finding G.

87) ACFC Second Opinion on Austria, para. 121.

88) ACFC Second Opinion on Sweden, para. 106.

89) Report of the Committee of Experts on the UK, second monitoring cycle, para. 234.

90) ACFC Second Opinion on Norway, para. 111; ACFC Opinion on Poland, para. 67, ACFC Second Opinion on Bosnia and Herzegovina, paras. 159 and 160.

91) Report of the Committee of Experts on Hungary, initial monitoring cycle, para. 61.

92) ACFC Second Opinion on Finland, para. 112; ACFC Second Opinion on Slovak Republic, paras. 88-89; ACFC Second Opinion on Moldova, para. 95; ACFC Opinion on Croatia, para. 44; ACFC Second Opinion on Kosovo, para. 77. See also Recommendation RecCHL(2001)3 on the Application of the Charter in Finland, Recommendation 3.

93) ACFC Second Opinion on Armenia, para. 82. 
or minority language speakers seem to be fairly well-informed about their rights, the government needs to encourage in a more pro-active manner the use of these languages in certain domains of public life, including those where there may not have been such practice in the past. This is all the more important against the background of a decreasing number of regional or minority language speakers, a tendency of assimilation and decreasing use of regional or minority languages in administration. ${ }^{94}$

Contrary to the Croatian experience, the Committee of Experts welcomes the proactive measures taken by Danish authorities with regard to German speakers and calls them "a model for other [...] administrative authorities". Some of these measures include: one-third of the employees of the State County Office are fluent in German; for documents in German, no translation is required from applicants; emails received in German are answered in German; special attention is given to the German skills of applicants in the recruitment procedure; when planning for holidays, the Office makes sure that at all times there is at least one staff member who speaks German. ${ }^{95}$

While recognising that it is the free choice of persons belonging to national minorities to make use or not of the legal possibilities open to them, authorities should nevertheless take additional measures to raise awareness amongst these persons of their rights in this sphere.

\section{Conclusions}

The article has addressed an extremely difficult question: namely, the extent to which a state must put aside its own exclusive language preferences and permit, or even require, public authorities to use a national minority language in addition to an official one.

The often-held belief that a state must be united by a common or, in extreme views, exclusive working language used by public authorities is confronted today with the option of the co-existence of the state and minority languages. An important platform, or even a minimum standard, for the use of minority languages before public authorities has been set up by the ECHR, and to a greater extent by the ECRML and the FCNM. No less important has become the monitoring practice of the independent committees of experts under the latter instruments, which has indeed become a real and dynamic vehicle for constructive criticism and the exchange of experiences.

\footnotetext{
94) Report of the Committee of Experts on Croatia, third monitoring cycle, Finding D.

95) Report of the Committee of Experts on Denmark, second monitoring cycle, paras. 74-76 and Finding G.
} 
In terms of the use of a minority language in public administration, where justified and reasonable to do so, a state must, to the limit of its abilities, respond in a proportionate way to the language preferences of its population. To put it in simple words, where the speakers of minority languages reside compactly, public authorities must provide for an increasing use of minority languages as the number of speakers of those languages becomes greater. Starting with the weaker obligations of the sliding-scale model proposed by de Varennes and going towards stronger obligations, this might mean ensuring the translation into minority languages of widely used administrative texts and forms; accepting oral or written applications in the minority language; responding to oral or written applications in the minority language in that language; providing a sufficient number of civil servants able to deal with minority language speakers; and using the minority language as an internal language of work within public administration.

Over the past decades a growing number of European states have agreed to take measures in response to the presence of linguistic minorities in their territories, including in their dealings with such minorities. However, as the above analysis has shown, in the realm of the Framework Convention and the Language Charter, the use of minority languages before administrative authorities is still a matter of concern. There are indications that the practical implementation of the obligations under the two instruments varies considerably from country to country. There are examples of good practice, but there also multiple examples of total absence of implementation. The possibility for the speakers to use their regional or minority language in their dealings with public administration is still weak and not sufficiently supported in many European states. And even where it is formally fulfilled, due to practical obstacles no use is made of the possibilities of the use of minority languages before public authorities. Thus, there is need for additional measures aimed at making this right operational. These could be legislative initiatives but also simple practical steps often dependent simply on the will of those concerned. As the old saying goes, "where there is a will, there is a way". To put it differently, "where there is a will to use a minority language, the way needs to be found". 
